\title{
Performed Histopathology Differentiation Grade Code
}

National Cancer Institute

\section{Source}

National Cancer Institute. Performed Histopathology Differentiation Grade Code. NCI

Thesaurus. Code C93918.

A coded value specifying the degree of cellular differentiation in a tissue sample. 